\title{
3. A Ceylon Embassy to Egypt.
}

In the Indian Antiquary, 1885, p. 61, Mr. Howorth quotes Maqrīii's account of an embassy sent from the King of Ceylon to the Sultān of Egypt. According to Mr. Howorth, the name of the Sinhalese King is Abu Nekbah Lebadahs. But the date is April, 1283, when Bhuvaneka Bāhu the First was reigning in Ceylon (see Mahāvansa, ed. Wijesinha, p. 314, for the chronicler's account of him, and my 'Ancient Coins and Measures of Ceylon,' plate i., for a photograph of his kahäpanas, which have been found in considerable numbers). It is clear that Bunekbah (there is no initial A in the Arabic) in the English transliteration of Maqrizi's Arabic reproduction of this Ceylon name corresponds to Bhuvaneka-bāhu, so that we have here an undesigned confirmation of the sometimes doubted chronology of the Ceylon chronicles. The other half of the name is curious. Quatremère, in his translation, from which Mr. Howorth is quoting, has, not Lebadahs but Lebabah, and in the Arabic text given on p. 176 he has جية أو كسا صاحب, which is apparently only. Suhib - a title naturally added to the name of a foreign king.

T. W. RhYs Davids.

4. Modern Name of Ur of the Chaldees.

Queen's College, Oxford,

Nov. $10 t h, 1890$.

SIR,-If Sir James Redhouse will refer to my " Hibbert Lectures," he will see that I have never written the modern name of Ur of the Chaldees "Mugh-ir." Like other Assyriologists, I have followed what is now the traditional mode of transcribing the name, Mugheir.

If I am not mistaken, Sir James Redhouse's explanation of the name as the Arabic Muqayyar is supported by Mr. Hormuzd Rassam, who has heard it so pronounced on the spot. Nevertheless, I have a suspicion that Loftus by his $g h$ intended to represent the Arabic ghain.

A. H. SAYce. 